\title{
A Review of UK based Multi-Agency Approaches to Early Intervention in Domestic Abuse: Lessons to be Learnt from Existing Evaluation Studies
}

Professor Karen Cleaver

Head of Department, Family Care \& Mental Health, Professor of Institute of Integrated Care.

University of Greenwich

Professor Pam Maras

Director of Research \& Enterprise, Professor of Social \& Educational Psychology.

University of Greenwich

Charlotte Oram

Assistant Statistician, Department for Education London; formerly research fellow,

University of Greenwich

Karen McCallum

Research Fellow, Department of Psychology, Social Care and Counselling

University of Greenwich 


\begin{abstract}
This paper presents a review of 22 published evaluations which examined domestic abuse interventions across the UK. A literature Search was conducted in November 2016. The main aim of the review was to identify emerging good practise in multi-agency early intervention; thus, to be eligible for inclusion in the review, projects were multi-agency in nature and aimed to intervene early. Findings from the review reveal that there are a range of strategies and interventions that have been piloted and tested which have had varying degrees of success. Overall, interventions that adopt an advocacy approach appear to have more impact and are more sustainable, and, that when co-located with statutory or voluntary services, multi-agency working is enhanced. However, further consideration is required in terms of what constitutes early intervention, as all interventions are dependent on victims and perpetrators accessing services early, thus, primary prevention strategies, currently entirely school based, are key to promoting and supporting secondary prevention.
\end{abstract}

Keywords: Domestic abuse; domestic violence; early interventions; multi-agency working; Key findings

- Early interventions that adopt a multi-agency approach are an established strategy for tackling root cases of societal problems including domestic violence and abuse.

- There is evidence to suggest that using strategies such as inter-agency information sharing, co-location, multi-disciplinary teams and integrated programmes for perpetrators and victims, may all support reduced risk and improved outcomes for victims, perpetrators and their families.

- Early interventions that adopt an advocacy based approach have a more sustainable impact on victims.

- What constitutes early intervention in domestic violence and abuse is not clearly 
defined and most existing research and evaluation frameworks do not apply a longitudinal approach to measuring and understanding these phenomena, inhibiting the establishment of effective early intervention strategies. 


\subsection{Introduction}

The aim of this review is to identify existing good practice in multi-agency, early intervention approaches to domestic abuse in the UK, as well as to note the potential challenges/barriers that may impede their wider roll-out and implementation, with a specific focus on the roles and responsibilities of those involved. The analysis considers barriers and opportunities of multi-agency working in the delivery of primary, secondary and tertiary early interventions, as defined in section 1.4 below.

This review was conducted as part of a wider project funded by Health Education England and was undertaken in collaboration with the London Metropolitan Police. The project arose in response to a report published by Her Majesty's Inspectorate of Constabulary (HMIC 2014). The HMIC had reviewed the police response to domestic abuse and found significant weaknesses in the police services provided to victims of domestic abuse and required forces to take urgent action to improve both their ways of working and to make their services more effective (HMIC 2014). At the time of the HMIC report rates of domestic abuse across South London were increasing, thus this in response to these concomitant challenges a survey of the Metropolitan Police response to domestic abuse was undertaken as well as a review of multiagency intervention across the UK. The review sought to better understand the UK profile of early interventions with the aim of preventing and managing the observed rise of domestic abuse in South London. The term multi-agency is problematized in the following section on terminology but for now multi-agency work simply means the phenomenon of multiple public and third sector agencies together providing programmes and services to clientele. 


\subsection{Background}

Globally, domestic abuse represents a significant societal, public health and economic problem and, although men and women are both regularly victimised, women are more likely than men to survive or be victimised by domestic abuse. It is known that $35 \%$ of women worldwide have experienced either physical and /or sexual intimate partner violence or nonpartner sexual violence and almost one third (30\%) of all women who have been in a relationship have experienced physical and/or sexual violence by their intimate partner (WHO 2013). It is estimated that globally $14 \%$ of homicides are committed by an intimate partner with more than a third of female homicides perpetrated by an intimate partner, which is commonly the culmination of a long history of abuse (Stockl et al 2013; WHO 2013). In the UK in the year ending March 2016, there were an estimated 1.8 million adults aged 16 to 59 who identified as a victim of domestic abuse, with domestic abuse-related crimes representing $10 \%$ of all crimes (Office for National Statistics 2016).

Domestic abuse has wide reaching consequences for victims of all genders. In addition to physical injury, there is increased risk of chronic illness, sexually transmitted infections and unwanted and complicated pregnancies (DOH, 2010; WHO 2013). Domestic abuse also has an adverse impact on mental health and has been linked to the actuation of post-traumatic stress disorder, long-term anxiety, depression, substance misuse, self-harm and suicide attempts (BMA, 2014; Campbell, Laughon \& Woods, 2006). Further, domestic abuse has been shown to have profound effects on children (Chan \& Yeung 2009) and to be a major contributing factor to children becoming street involved (Netto, Pawson \& Sharp, 2009). Studies demonstrate the inter-generational consequences for children exposed to chronic abusive and violent behaviours, linking child victimisation to poor educational achievement and health outcomes (Guy, Feinstein \& Griffiths, 2014). 
Relatedly, domestic abuse has significant economic consequences. The estimated global cost of intimate partner violence alone is over 5\% of the world's GDP (Hoeffler \& Fearon, 2015). In 2009, researchers estimated that the cost of domestic abuse to UK public services was $£ 3.85$ billion, with $£ 1.7$ billion spent by the NHS responding to the physical and psychological impact on victims' health (Walby, 2009). There are therefore public health, economic as well as ethical imperatives to intervene early to prevent escalation of domestic abuse and to establish early intervention strategies that span statutory and non-statutory agencies, requiring multi-agency working.

Multi-agency working is not without its challenges. Whilst it has been found to be rewarding and stimulating for practitioners, leading to a greater understanding of other agencies and services, it can also result in uncertainty over professional identity and professional status, which have been identified as barriers to effective multi-agency working (Atkinson et al 2005, Moran et al 2007, O’Carroll et al 2016).

\subsection{Terminology}

The term domestic abuse as defined by the UK Home Office (2012) is used throughout this paper (other than when referring to publications where alternative terminology is used). Their definition of domestic abuse reflects the exploitative, controlling and coercive behaviours of perpetrators, while also encompassing the physical and psychological violence associated with aggression. The UK Home Office acknowledges that several terms are used interchangeably, including domestic violence and intimate partner violence. Likewise, although 'multi-agency working' is used as a term within the paper, it is acknowledged that a plethora of terms exists which describe working practices that include more than one service provider, including inter-professional working and inter-agency working, which are often 
used interchangeably.

\section{$1.3 \quad$ Multi-agency Working and Domestic Abuse}

Victims of domestic abuse access multiple agencies, including police, social services, advocacy, health and social care and housing programmes, and often require multiple services to stay safe and rebuild their lives (Home Office, 2014a). Multi-agency working is viewed as the most effective way to approach domestic abuse at both an operational and strategic level (NICE 2014), leading to more holistic, streamlined and effective service delivery (Fox \& Butler, 2004). Improvements in inter-professional relations and communications and improved wellbeing amongst professionals are some of the observed benefits to multi-agency working (Atkinson et al 2002, 2007). However, as Warmington et al (2004) note, much of the policy and strategic literature emphasises and perpetuates the notion that multi-agency working is a "virtuous solution to joined up social problems," while "under-acknowledging that it is a site of tensions and contradictions rather than an ideal model of service delivery" (Warmington et al 2004:7). There are numerous challenges to multi-agency working (Atkinson et al 2002, 2005), including issues around funding and resources, roles and responsibilities, competing priorities, communication, professional and agency culture and management, including professional silos and hierarchies, organisational barriers such as geographically distributed teams, and lack of training across the workforce (Atkinson et al 2001, Hill \& Secker 2001, Sloper 2004, Laming 2009, Gasper 2010, Stevens 2013, O’Carroll et al 2016).

New reforms were implemented in the UK to support enhanced multi-agency responses to domestic abuse following the introduction of the Domestic Violence, Crime \& Victims Act 2004 (UK Government, 2004),. These include the establishment of Specialist Domestic Violence Courts (SDVC), Multi-agency Risk Assessment Conferences (MARAC), which 
bring together statutory and non-statutory agencies to coordinate community responses to domestic abuse, and Independent Domestic Violence Advocates (IDVAs), to support highrisk victims of domestic abuse through the criminal justice system. These reforms have, it is suggested, provided platforms to deliver specialised support by enabling local agencies to work together closely and cost effectively (Safe Lives 2016). However, Harvie and Manzie (2011) propose that in the UK the identification of the Home Office as the lead government department for domestic abuse has resulted in a cultural and legal shift -- domestic abuse is now located within a criminal justice and disorder framework, as opposed to embedded within a feminist / women's movement discourse. This move has resulted in the displacement of feminist theory and a reduction of its political power as a dominant mode for interpreting and analysing issues, while replacing it with prescriptive short-term performance measures that prevail over long-term victim orientated responses (Harvie \& Manzie 2011).

\subsection{Early Intervention and Domestic Abuse}

Early interventions, which aim to tackle root causes of problems before they become entrenched, are increasingly the focus for preventative measures and are key to reducing domestic abuse (Barran 205). However, Guy et al (2014:16) propose that existing approaches to early interventions are largely untested. Guy et al (2014) outline three forms of preventive public service activity that respond to specific challenges of domestic abuse: (1) universal services responsible for embedding an understanding of good relationships in childhood and adolescence (primary prevention); (2) early intervention to support social and emotional skills and provide other support to groups such as young mothers who are particularly at risk (secondary prevention) and (3) work to support victims, safeguard children and reduce the recidivism of perpetrators (a mixture of acute services and tertiary prevention). In line with the approaches to early intervention in domestic abuse as outlined above by Guy et al (2014), 
early interventions are classified as those that are school based and/or targeted at children and young people, or those which provide support to victims and their families, including perpetrators.

This review considers all 3 forms of preventative public service activity listed above, as well as the third type, because the definition of early intervention used has been extended to also include early interactions between service users and providers, an approach further justified below. This approach is holistic enough to capture interventions that aim to make a difference as early as possible to prevent and break cycles of domestic abuse.

In line with Guy et al's (2014) definitions of early interventions, the findings drawn from the evaluation studies are discussed according to their designation as primary, secondary or tertiary interventions. Hester \& Westmarland (2005) note that "primary prevention is a longterm strategy aimed at preventing violence from ever happening by changing the attitudes, values and structures that sustain inequality and violence" (Hester \& Westmarland 2005:15). Consequently, much focus in primary prevention is on children and young people and initiatives occurring in schools. However, there are few evaluations of school-based intervention programmes in the UK (Fox et al 2016). Those that have been conducted suggest that schools-based schemes can improve knowledge and understanding of domestic abuse in young people.

The term secondary intervention is used to include interventions that provide support social and emotional skills training as well as provide other types of support to groups known to be at a high risk of experiencing domestic abuse, such as young mothers. Tertiary interventions include work to support victims, safeguard children and reduce the recidivism of perpetrators.

It was found that in practice some service agencies considered early intervention to encompass providing services for both victims of domestic abuse the first time they accessed 
services, as well as for first-time perpetrators or perpetrators of relatively minor offenses. These two preventative services would be classified comfortably as tertiary in the above scheme, though the service providers consider them early interventions in the sense that they aim to intervene very early in the abuse cycle.

A key point to remember when considering 'early' intervention is that domestic abuse victims may wait considerable time before disclosure, suggesting that early detection and intervention systems are needed even though they may be introduced after abuse has begun. Evans and Feder (2015) found that women experiencing domestic abuse needed earlier access to specialised services but many delayed making contact until a crisis occurred, or an 'enabler' (i.e. an individual) facilitated initial access. The women developed strategies for dealing with their abuse and faced complex personal and logistical barriers to disclosure, such as denial or failure to recognise abuse, self-blame, mistrust of service providers or fear of repercussion from the perpetrator (Evans and Feder 2015) which suggests that facilitating early intervention may be a long-term, complex process.

Where tertiary level prevention strategies have been identified, they appear commensurate with this idea of early intervention, convincing us to both include them and to incorporate them together under the subheading of secondary and tertiary prevention. In Table 2, each study is identified as primary, secondary or tertiary for reference.

The paper does not attempt to compare multi-agency models of early intervention, of which there are many (Atkinson, et al 2007), but rather points to promising practises and opportunities within existing multi-agency frameworks and partnerships.

\subsection{Methods}

A three-step strategy was undertaken to identify UK papers published between 2005-2016 
that reported an evaluation of early interventions in domestic abuse. The review began in 2015 and sought to capture data on the past 10 years of intervention evaluations. The review was completed a year after it began, resulting in the inclusion criteria timeframe of 20052016. The logic of this timescale was to allow for the capture of intervention practices that spanned multiple political changes but that were undertaken within a current policy framework. Remembering that the purpose of this study was to understand a current problem from within a specific national context, an eleven-year timeframe for review capture appears robust in its scope.

Papers reporting on UK-based good practise in early intervention initiatives were selected. These papers included those that identified strategies that might be adopted by local agencies and had to be applicable to the delivery of UK-based statutory and voluntary services. The final search was undertaken in November 2016.

\subsection{Search Strategy}

In stage one, EBSCOhost was used to access the education, health sciences and psychology/sociology databases. This enabled access to the following databases:

- Academic Search Premier

- Cinhal Plus with full text

- Education research complete

- Humanities research complete

- Psychology and behavioural science collection

- PsychINFO

- Teacher reference center

- Medline

- Sportdiscus

- PsychARTICLES

Search terms used were: "domestic abuse or domestic violence," AND "multi-agency or inter-professional or interagency working," AND "early intervention," AND "evaluation”. A total of 21,818 results were returned. After applying parameters of date (2005-2016), 
publication language (academic journals in English Language) and country of intervention delivery (undertaken in the UK) 178 papers remained, which were reduced to 163 following the removal of duplicates.

Stage two entailed the screening of located papers for relevance. As the aim of this review was to explore early interventions in domestic abuse, the minimum criteria for inclusion were papers reporting on an early intervention initiative that was comprised of a minimum of two independent agencies. Those studies or reviews that exclusively addressed interventions for the highest risk individuals, for example, research evaluating the work of multi-agency risk assessment committees, were excluded, as were those that focused solely on child abuse. The most high-risk domestic abuse intervention cases were excluded from our analysis because of our focus on early intervention. High-risk domestic abuse cases usually arise from the escalation of violence over a period of time and the needs of the affected family are importantly different from the cases considered here, which include those with first time offenders (Stöckl 2013).

After following the application of inclusion criteria, 6 peer-reviewed papers remained. Stage three of the search involved following up on published papers retrieved to locate grey literature involving web-based reports; a Google Scholar search was also conducted after hand-searching the reference list of the eligible papers identified. A further 15 papers/reports were located and assessed as eligible for inclusion (see Figure 1). 

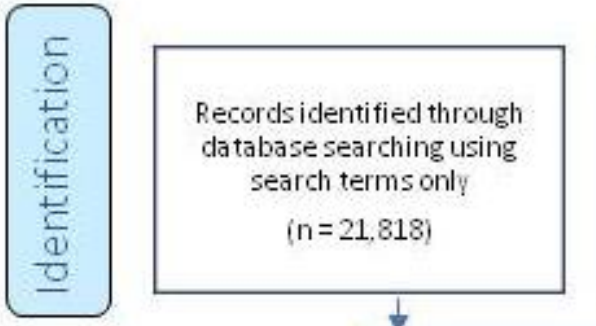
Recordsidentified through
Google Scholar, follow up of
references and a personal contact $(n=16)$
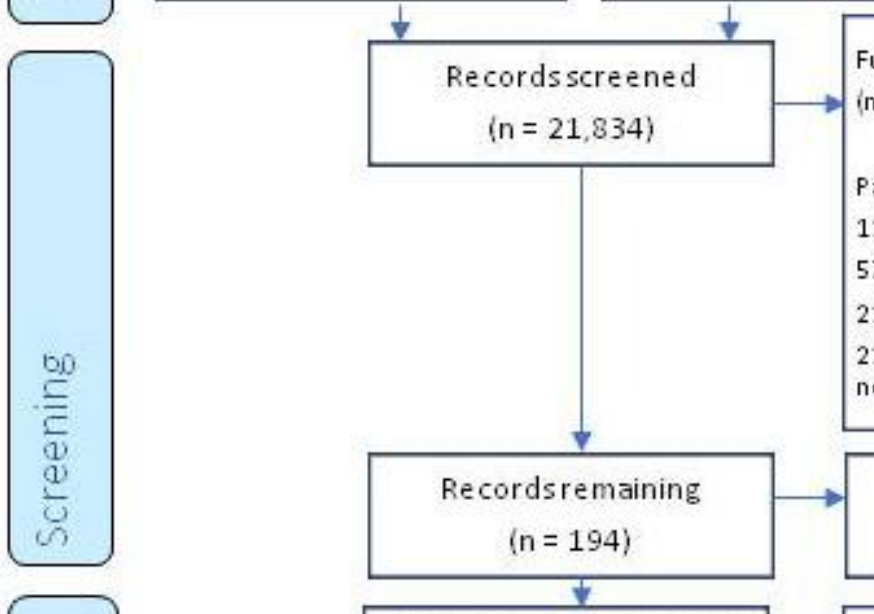

Full-t ext records excluded in $=21,640$ )

Papersexcluded afterscreening: 11,919 out side dat e range; 5790 not peer reviewed; 21,340 not undert aken in UK.

21,640 date range + or, not peer reviewed, + or, not undertaken in UK (duplicates removed)
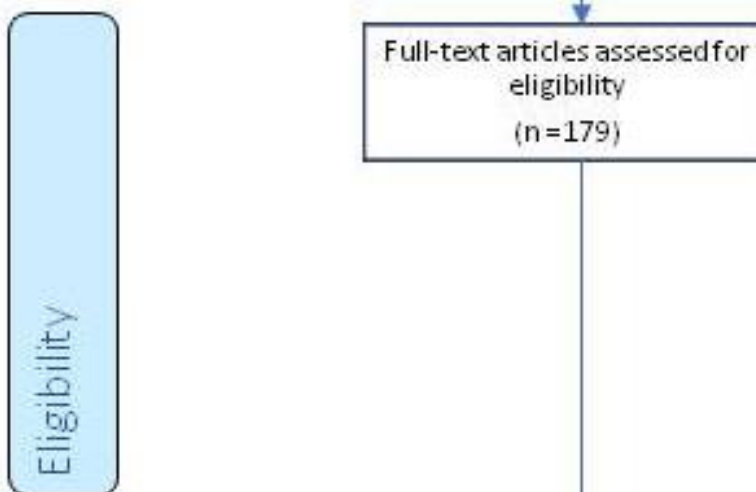

Duplicates removed $(n=15)$
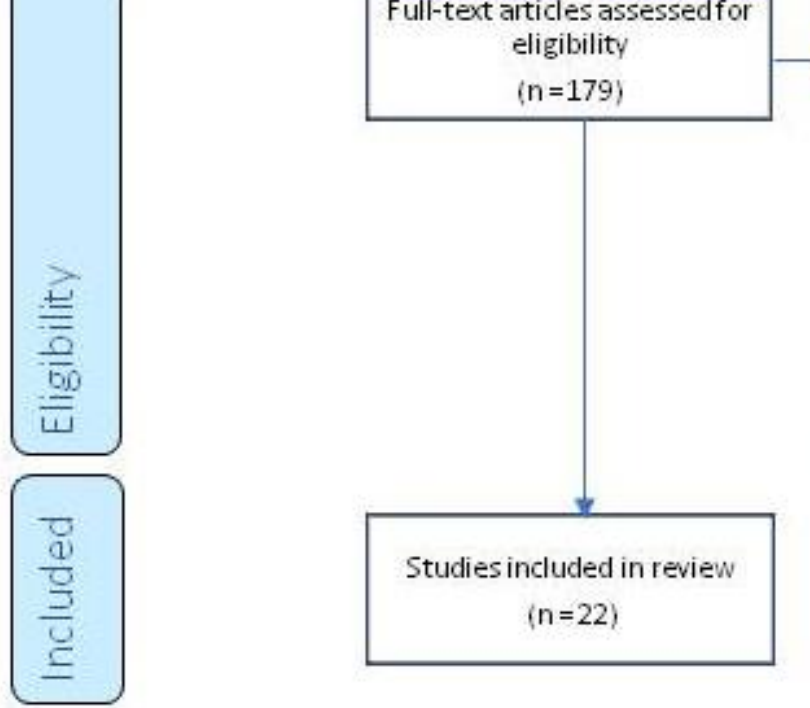

Full-text records excluded in $=157$ )

Papers excluded for ine ligibility:

26 not relevant

13 multiagency working but not domestic abuse

18 focus was specifict o child safe guarding

22 mono-agency involvement

13 not early enough intervention

65 papers reported were discussion and or opinion pieces

\subsection{Appraising Selected Papers}

Papers were analysed inductively to identify factors that indicated success or otherwise of multi-agency working across the initiatives and intervention strategies reviewed. The studies reviewed adopted a range of methods within and across projects to evaluate the effectiveness of interventions, although most commonly interviews or focus groups were employed. 
Debates about how best to appraise the success of evaluation studies abound with a range of typologies developed (O’Connell et al 2017). These typologies commonly adopt the principles employed when critically appraising scientific papers, which are therefore orientated towards quantitative scientific approaches to research. For example, within the context of evidence-based medicine the randomised controlled trial is considered the most rigorous approach for determining a causal relationship and is located at the top of a research design hierarchy (Greenhalgh 2014). The rigour of RCT's contribute to their value in evaluation research are acknowledged (Rychetnik et al 2002). However, evaluation research might also consider more than the presence and strength of a causal relationship; researchers might also consider social processes and factors that might impinge on the success or not of an intervention as integral to its evaluation.

The appraisal of evidence about public health interventions should encompass not only the credibility of evidence, but also its completeness and transferability (Rychetnik et al 2002:125). The criteria identified by Rychetnik et al (2002) was adapted and used for this study (see Table 1), assessing early interventions against three categories with three measures per category using numerical coding indices. An intervention was encoded with a 1 if the measure was addressed and a zero if it was not addressed, with a maximum score of 9 available. Data were extracted into an excel worksheet where meta data was also included such as the title and location of the project, the intervention, evaluation measures, and the outcomes of the appraisal of the studies. In some cases, authors published reports and peerreviewed research papers using the data and in these cases it is indicated that the grey literature and peer-reviewed article or chapter outcomes share the same meta data and were derived from the same research (see Table 2).

The search identified studies and reports which described and evaluated projects employing 
wide ranging interventions to support victims, their children and, to a lesser extent, perpetrators of domestic abuse (see Table 1). In some instances, multiple publications addressed a strand of work evaluating a range of interventions/initiatives; to manage the review, where relevant, the projects were grouped together (see Table 2). The number of agencies involved ranged from $2-12$ and represented studies in geographical locations across the UK, except for Northern Ireland; projects based in London were greater in number. The projects mainly focused on female, heterosexual victims of domestic abuse in intimate relationships and male perpetrators of abuse. 
Table 1: Criteria used to critically appraise the evaluation studies

\begin{tabular}{|c|c|}
\hline Domain of assessment and central factor of consideration & Secondary queries \\
\hline $\begin{array}{l}\text { IS THE RESEARCH GOOD ENOUGH? } \\
\text { Why an intervention appears to be effective or ineffective }\end{array}$ & $\begin{array}{l}\text { 1. What is the strength of evidence, as determined by the study design (level), } \\
\text { methodological quality and statistical precision? } \\
\text { 2. What is the magnitude of the measured effects? } \\
\text { 3. Is there relevance of the measured effects (as observed in the evaluation) to the } \\
\text { implementation context? }\end{array}$ \\
\hline $\begin{array}{l}\text { WHAT ARE THE INTERVENTION OUTCOMES? } \\
\text { Who do the interventions cover, are they anticipated and how efficient } \\
\text { and effective are they? }\end{array}$ & $\begin{array}{l}\text { 1. Do the outcome variables cover the interests of all the important stakeholders? } \\
\text { 2. Are there unanticipated outcomes? if so are they as desirable as, or more desirable than, } \\
\text { the intended effects of the intervention } \\
\text { 3. Has efficiency has been assessed, and if so, how well.? }\end{array}$ \\
\hline $\begin{array}{l}\text { IS THE RESEARCH EVIDENCE TRANSFERABLE? } \\
\text { How transferable is the intervention, intervention context and what are } \\
\text { the interactions between the intervention and its context? }\end{array}$ & $\begin{array}{l}\text { Does the evaluation detail: } \\
\text { 1. The design, development and delivery of intervention strategies. } \\
\text { 2. The characteristics of people for whom the intervention was effective, and of those for } \\
\text { whom it was less effective or even harmful? } \\
\text { 3. Contextual background and detail } 3\end{array}$ \\
\hline
\end{tabular}

Adapted from Rychetnik et al (2002) 
Table 2: Summary of Evaluation Studies Included in the Review

\begin{tabular}{|c|c|c|c|c|c|c|}
\hline $\begin{array}{l}\text { Citation } \\
\text { reference }\end{array}$ & $\begin{array}{l}\text { Grey lit. or } \\
\text { Peer- } \\
\text { reviewed }\end{array}$ & $\begin{array}{l}\text { Level of } \\
\text { intervention }\end{array}$ & $\begin{array}{l}\text { Agencies } \\
\text { involved }\end{array}$ & Interventions & Evaluation measures & Summary of findings \\
\hline $\begin{array}{l}\text { Bacchus et } \\
\text { al } 2010\end{array}$ & Peer & Secondary & $\begin{array}{l}\text { NHS } \\
\text { Maternity } \\
\text { and sexual } \\
\text { services; } \\
\text { domestic } \\
\text { violence } \\
\text { advocacy } \\
\text { services. }\end{array}$ & $\begin{array}{l}\text { Guidelines and staff training } \\
\text { with inclusion of routine } \\
\text { enquiry for domestic violence } \\
\text { with all patients and referral } \\
\text { of women disclosing violence } \\
\text { to an on-site advocacy } \\
\text { service. }\end{array}$ & $\begin{array}{l}\text { 1. Assumption } \\
\text { querying } \\
2 . \quad \text { Interviews with } \\
\text { service providers and } \\
\text { patients, reviews of } \\
\text { patient records, pre- and } \\
\text { post-training } \\
\text { questionnaires }\end{array}$ & $\begin{array}{l}\text { - Domestic violence training resulted in } \\
\text { short-term changes in health professionals' } \\
\text { knowledge and practice. Universal routine } \\
\text { enquiry was not achieved even in a context of } \\
\text { organisational support, guidelines, training and } \\
\text { advocacy. } \\
\text { - Potential and actual harm occurred, } \\
\text { including breaches of confidentiality and failure } \\
\text { to document evidence, limiting women's ability } \\
\text { to access civic and legal remedies } \\
\text { - Advocacy support led to positive } \\
\text { outcomes for many women, if support to } \\
\text { maintain positive changes, whether women } \\
\text { stayed with or left violent partner, continued to } \\
\text { be given. Maternity and sexual health services } \\
\text { were found to be opportune points of intervention } \\
\text { for domestic violence services that combine } \\
\text { routine enquiry by clinicians with support after } \\
\text { disclosure and attention to harm reduction. }\end{array}$ \\
\hline $\begin{array}{l}\text { Clarke \& } \\
\text { Wydall } 2013\end{array}$ & Peer & Tertiary & $\begin{array}{l}\text { Twelve } \\
\text { statutory and } \\
\text { voluntary } \\
\text { sector } \\
\text { agencies, } \\
\text { including the } \\
\text { police, the } \\
\text { probation } \\
\text { service, } \\
\text { Foundation } \\
\text { Housing and } \\
\text { specialist } \\
\text { domestic } \\
\text { abuse } \\
\text { services, }\end{array}$ & $\begin{array}{l}\text { Advocacy and support } \\
\text { for adult victims } \\
\cdot \quad \text { Support for children } \\
\text { and young people } \\
\cdot \quad \text { Accommodation and } \\
\text { key worker support for } \\
\text { perpetrators while they are } \\
\text { attending the program } \\
\cdot \quad 12 \text { statutory and } \\
\text { voluntary sector agencies } \\
\text { including the police, the } \\
\text { probation service, foundation } \\
\text { housing and specialist DA } \\
\text { services funded by the } \\
\text { National Society for the }\end{array}$ & 1. Interviews & $\begin{array}{l}\text { Rehousing the perpetrator relieves } \\
\text { victims/survivors and their children's anxiety and } \\
\text { prevents the victims/survivors' hardship } \\
\text { associated with homelessness }\end{array}$ \\
\hline
\end{tabular}




\begin{tabular}{|c|c|c|c|c|c|c|}
\hline $\begin{array}{l}\text { Citation } \\
\text { reference }\end{array}$ & $\begin{array}{l}\text { Grey lit. or } \\
\text { Peer- } \\
\text { reviewed }\end{array}$ & $\begin{array}{l}\text { Level of } \\
\text { intervention }\end{array}$ & $\begin{array}{l}\text { Agencies } \\
\text { involved }\end{array}$ & Interventions & Evaluation measures & Summary of findings \\
\hline & & & $\begin{array}{l}\text { including } \\
\text { child support } \\
\text { workers. } \\
\end{array}$ & $\begin{array}{l}\text { Prevention of Cruelty to } \\
\text { Children (NSPCC) }\end{array}$ & & \\
\hline $\begin{array}{l}\text { Coy \& Kelly } \\
2011\end{array}$ & Grey & Secondary & $\begin{array}{l}\text { Police; NHS } \\
\text { Third sector } \\
\text { agencies } \\
\text { specialising } \\
\text { in DA }\end{array}$ & $\begin{array}{l}\quad \text { Support from IDVAs } \\
\text { co-located in a police station; } \\
\text { hospital A\&E department; } \\
\text { A community based } \\
\text { domestic violence project; } \\
\text { and a women-only violence } \\
\text { against women (VAW) } \\
\text { organisation. }\end{array}$ & $\begin{array}{l}\text { 1. IDVA interviews } \\
\text { 2. Observation visits } \\
\text { 3. Observation of } \\
\text { MARACs } \\
\text { 4. Stakeholder } \\
\text { interviews } \\
\text { 5. Interviewing } \\
\text { national experts }\end{array}$ & $\begin{array}{l}\text { - Advocacy and support from IDVAs } \\
\text { enabled women to feel safer and increased their } \\
\text { knowledge of available options } \\
-\quad 1 / 3 \text { of all cases were closed with service } \\
\text { user's needs met, in } 15.7 \% \text { cases } \\
-\quad \text { Risk was reduced, } 2 / 3 \text { of cases reported no } \\
\text { further violence after contact with IDVA }\end{array}$ \\
\hline $\begin{array}{l}\text { Donovan et } \\
\text { al } 2010\end{array}$ & Grey & Tertiary & $\begin{array}{l}\text { Third sector } \\
\text { agencies } \\
\text { specialising } \\
\text { in DA; } \\
\text { IDVA's, } \\
\text { Police and } \\
\text { LA's }\end{array}$ & $\begin{array}{l}\text { Two projects } \\
\text { established which provided 1- } \\
1 \text { support to victim/survivors, } \\
1-1 \text { group work for children, } \\
\text { and a voluntary perpetrator } \\
\text { programme } \\
\cdot \quad \text { Risk assessment, safety } \\
\text { planning, needs assessment } \\
\text { carried out by IDVAs }\end{array}$ & $\begin{array}{l}\text { 1. Monitoring repeat } \\
\text { referrals } \\
\text { 2. Interviews }\end{array}$ & \multirow{2}{*}{ 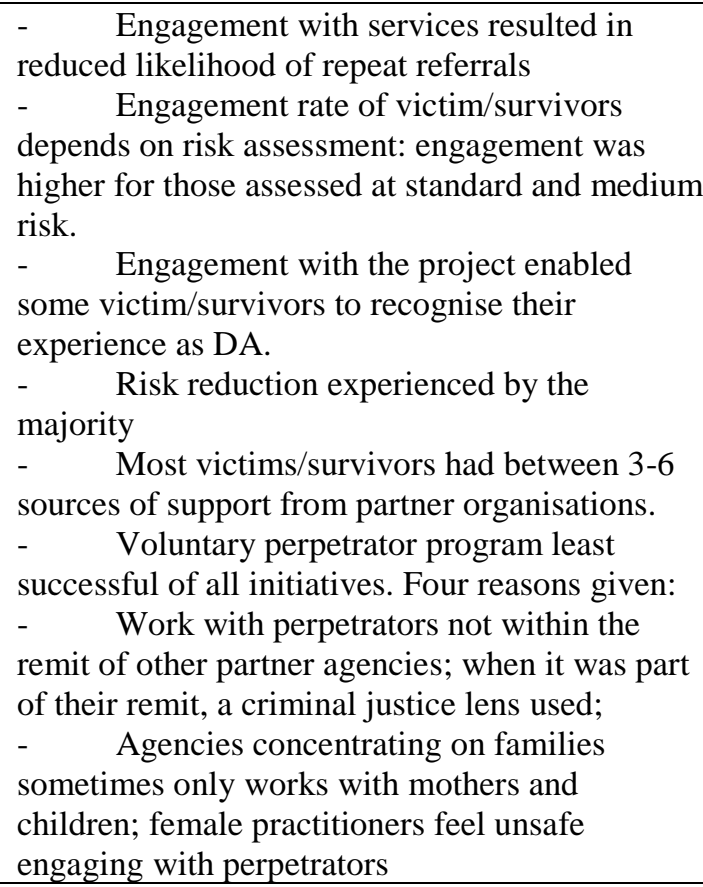 } \\
\hline $\begin{array}{l}\text { Donovan \& } \\
\text { Griffiths } \\
2015\end{array}$ & Peer & Tertiary & & & & \\
\hline
\end{tabular}




\begin{tabular}{|c|c|c|c|c|c|c|}
\hline $\begin{array}{l}\text { Citation } \\
\text { reference }\end{array}$ & $\begin{array}{l}\text { Grey lit. or } \\
\text { Peer- } \\
\text { reviewed }\end{array}$ & $\begin{array}{l}\text { Level of } \\
\text { intervention }\end{array}$ & $\begin{array}{l}\text { Agencies } \\
\text { involved }\end{array}$ & Interventions & Evaluation measures & Summary of findings \\
\hline $\begin{array}{l}\text { Evans and } \\
\text { Feder } 2014\end{array}$ & Peer & Tertiary & $\begin{array}{l}\text { Primary Care } \\
\text { trusts; } \\
\text { Specialist } \\
\text { domestic } \\
\text { violence } \\
\text { advocacy } \\
\text { services }\end{array}$ & $\begin{array}{l}\quad \text { Practice-based training } \\
\text { sessions, a prompt within the } \\
\text { medical record to ask about } \\
\text { abuse, referral pathway to a } \\
\text { named DA advocate who also } \\
\text { delivered the training and } \\
\text { further consultancy. }\end{array}$ & $\begin{array}{l}\text { 1. Monitoring referrals } \\
\text { to DA advocate services } \\
2 . \quad \text { Recorded } \\
\text { identification of domestic } \\
\text { violence in the electronic } \\
\text { medical records of the } \\
\text { general practice }\end{array}$ & $\begin{array}{l}\text { - Access to specialist support rarely resulted } \\
\text { from general practice despite presence of high } \\
\text { levels of anxiety and depressed feelings. } \\
\text { - Training and support programme targeting } \\
\text { primary care practitioners and administrative } \\
\text { staff improver referral to specialist domestic } \\
\text { violence agencies and recorded identification of } \\
\text { women experiencing domestic violence. }\end{array}$ \\
\hline $\begin{array}{l}\text { Feder et al } \\
2011\end{array}$ & Peer & Tertiary & $\begin{array}{l}\text { Specialist } \\
\text { domestic } \\
\text { violence } \\
\text { advocacy } \\
\text { services }\end{array}$ & $\begin{array}{l}\text { Specialist domestic } \\
\text { violence and abuse agencies } \\
\text { that offer safe housing and } \\
\text { outreach in the community } \\
\cdot \quad \text { Psychological } \\
\text { Advocacy Towards Healing } \\
\text { (PATH) }\end{array}$ & $\begin{array}{l}\text { 1. Repeat interviews } \\
\text { with women survivors of } \\
\text { domestic violence and } \\
\text { abuse. }\end{array}$ & $\begin{array}{l}\text { - Abuse is often reported only after the } \\
\text { victim/survivor has left the perpetrator } \\
-\quad \text { Access to specialist support rarely resulted } \\
\text { from general practice despite presence of high } \\
\text { levels of anxiety and depressed feelings. } \\
\text { - Many women need an enabler to facilitate } \\
\text { access. }\end{array}$ \\
\hline $\begin{array}{l}\text { Fox et al } \\
2014\end{array}$ & Peer & Primary & $\begin{array}{l}\text { Schools, third } \\
\text { sector } \\
\text { agencies } \\
\text { specialising } \\
\text { in DA; }\end{array}$ & $\begin{array}{l}\text { School-based DA prevention } \\
\text { programs: Relationships } \\
\text { without fear (6 weeks, 8-16- } \\
\text { year-olds); La Mascara del } \\
\text { Amor (6 weeks 14-16-year- } \\
\text { olds); Filles et Garcons en } \\
\text { route pour l'Egalite (one off } \\
\text { session, 13-25 year-olds). }\end{array}$ & $\begin{array}{l}\text { 1. Questionnaires and } \\
\text { focus groups } \\
\text { 2. Attitudes Towards } \\
\text { Domestic Violence } \\
\text { Questionnaire (ADV) } \\
\text { 3. The Normative } \\
\text { Beliefs about Aggression } \\
\text { Scale (NOBAGS) } \\
\text { 4. Help seeking }\end{array}$ & $\begin{array}{l}\text { - Children who received the program } \\
\text { demonstrated less acceptance of DA and were } \\
\text { more likely to seek help from pre to post-test } \\
\text { compared to children who did not receive the } \\
\text { program (control group). } \\
\text { - Changes in attitude in the program } \\
\text { receivers were maintained after } 3 \text { months. } \\
\text { - } \quad \text { Preventative programs are more effective } \\
\text { if they are delivered over several weeks. }\end{array}$ \\
\hline
\end{tabular}




\begin{tabular}{|c|c|c|c|c|c|c|}
\hline $\begin{array}{l}\text { Citation } \\
\text { reference }\end{array}$ & $\begin{array}{l}\text { Grey lit. or } \\
\text { Peer- } \\
\text { reviewed }\end{array}$ & $\begin{array}{l}\text { Level of } \\
\text { intervention }\end{array}$ & $\begin{array}{l}\text { Agencies } \\
\text { involved }\end{array}$ & Interventions & Evaluation measures & Summary of findings \\
\hline $\begin{array}{l}\text { Fox et al } \\
2016\end{array}$ & Peer & Primary & & & questions & $\begin{array}{l}\text { - } \quad \text { Boys are generally less engaged with } \\
\text { relationship education and DA prevention } \\
\text { programmes than girls } \\
\text { - } \quad \text { Relationship education does not always } \\
\text { succeed in encouraging young people to seek } \\
\text { help from adults. } \\
\text { - Challenges to educators delivering the } \\
\text { programs includes children's own self- } \\
\text { perceptions, victim-blaming, and sexist }\end{array}$ \\
\hline $\begin{array}{l}\text { Hale et al } \\
2012 \\
\text { (included } \\
\text { out of } \\
\text { alphabetical } \\
\text { order to } \\
\text { keep with } \\
\text { Fox et al } \\
\text { 2016) }\end{array}$ & Grey & Primary & & & & $\begin{array}{l}\text { stereotypes. } \\
\text { - Soliciting young people's perspectives on } \\
\text { the content is key to enhance program } \\
\text { effectiveness. } \\
\text { - There is tension between educators giving } \\
\text { young people free expression to share their } \\
\text { opinions and challenge sexism and other } \\
\text { prejudices }\end{array}$ \\
\hline $\begin{array}{l}\text { Granville \& } \\
\text { Bridge } 2010\end{array}$ & Grey & Tertiary & $\begin{array}{l}\text { Primary } \\
\text { health care; } \\
\text { Third sector } \\
\text { agencies } \\
\text { specialising } \\
\text { in DA }\end{array}$ & $\begin{array}{l}\text { Face-to-face interviews } \\
\text { in the hospital and follow up } \\
\text { phone calls from IDVA } \\
\cdot \quad \text { IDVA carries out } \\
\text { actions on behalf of clients }\end{array}$ & $\begin{array}{l}\text { 1. Monitoring number } \\
\text { of referrals } \\
2 . \quad \text { Monitoring client } \\
\text { descriptions } \\
\text { 3. Training evaluations } \\
\text { and focus groups }\end{array}$ & $\begin{array}{l}\text { - } \quad \text { Safety of women and children improved } \\
-\quad \text { Early intervention with women } \\
\text { experiencing abuse in pregnancy occurred } \\
-\quad \text { The number of South Asian women using } \\
\text { the IDVA service in Manchester increased } \\
\text { - } \quad \text { Midwives response through routine } \\
\text { enquiry enhanced } \\
\text { - Increased competence in recognising and } \\
\text { responding to domestic abuse }\end{array}$ \\
\hline
\end{tabular}




\begin{tabular}{|c|c|c|c|c|c|c|}
\hline $\begin{array}{l}\text { Citation } \\
\text { reference }\end{array}$ & $\begin{array}{l}\text { Grey lit. or } \\
\text { Peer- } \\
\text { reviewed }\end{array}$ & $\begin{array}{l}\text { Level of } \\
\text { intervention }\end{array}$ & $\begin{array}{l}\text { Agencies } \\
\text { involved }\end{array}$ & Interventions & Evaluation measures & Summary of findings \\
\hline $\begin{array}{l}\text { Hague and } \\
\text { Bridge } 2008\end{array}$ & Peer & Tertiary & $\begin{array}{l}\text { Third sector } \\
\text { agencies } \\
\text { specialising } \\
\text { in DA; } \\
\text { housing; } \\
\text { police/probati } \\
\text { on services, } \\
\text { LAs }\end{array}$ & $\begin{array}{l}\text { The Data- } \\
\text { Collection/Monitoring } \\
\text { Project: to provide a county } \\
\text { wide coherent data- } \\
\text { monitoring system a. } \\
\text { The Police Project: to } \\
\text { enhance evidence gathering } \\
\text { and provide 'target } \\
\text { hardening', personal safety } \\
\text { videos and improved training } \\
\text { on domestic violence. } \\
\text { The Outreach/ } \\
\text { Advocacy Project: to provide } \\
\text { outreach support across the } \\
\text { county, running women's } \\
\text { support groups, and building } \\
\text { networks with women's } \\
\text { services. } \\
\text { The Education Project: } \\
\text { to develop domestic violence } \\
\text { programmes in schools. }\end{array}$ & $\begin{array}{l}\text { 1. Monitoring referrals } \\
\text { and repeat incidents } \\
\text { 2. Monitoring arrests } \\
\text { and prosecution }\end{array}$ & $\begin{array}{l}\text { There are considerable resource } \\
\text { implications to achieving co-ordinated data- } \\
\text { monitoring including the employment of } \\
\text { dedicated staff to organise it. } \\
\text { - Camera evidence is helpful in the } \\
\text { prosecution of domestic violence perpetrators, } \\
\text { but careful operational/management systems } \\
\text { need to be in place. } \\
\text { - In general, mobile phones/alarms appear } \\
\text { to work best in a support function when they are } \\
\text { part of a wider integrated strategy of support. } \\
\text { - Training for emergency staff taking calls, } \\
\text { as well as police, was also needed. } \\
\text { - Target hardening' including increasing the } \\
\text { security of accommodation and the provision of } \\
\text { personal alarms and mobile telephones to abuse } \\
\text { survivors with the aim of reducing repeat } \\
\text { incident, was successful } \\
\text { - Multi-agency co-ordination and joint } \\
\text { working are essential, and outreach projects } \\
\text { should meet children's needs as well as those of } \\
\text { women. Staff conducting outreach require } \\
\text { comprehensive training and support, together } \\
\text { with appropriate pay levels and secure } \\
\text { employment. } \\
\text { Education programmes are likely to be widely } \\
\text { welcomed by schools/teachers if they are } \\
\text { thoroughly prepared, sensitively conducted and } \\
\text { accompanied by pastoral support including in } \\
\text { handling disclosures. Coverage of domestic } \\
\text { violence issues can be the subject of successful } \\
\text { interventions at primary (as well as secondary) } \\
\text { school level. }\end{array}$ \\
\hline
\end{tabular}




\begin{tabular}{|c|c|c|c|c|c|c|}
\hline $\begin{array}{l}\text { Citation } \\
\text { reference }\end{array}$ & $\begin{array}{l}\text { Grey lit. or } \\
\text { Peer- } \\
\text { reviewed }\end{array}$ & $\begin{array}{l}\text { Level of } \\
\text { intervention }\end{array}$ & $\begin{array}{l}\text { Agencies } \\
\text { involved }\end{array}$ & Interventions & Evaluation measures & Summary of findings \\
\hline $\begin{array}{l}\text { Hester \& } \\
\text { Westmarlan } \\
\text { d } 2005\end{array}$ & Grey & Primary & $\begin{array}{l}\text { Police; Third } \\
\text { sector } \\
\text { agencies } \\
\text { specialising } \\
\text { in DA; } \\
\text { housing; } \\
\text { police/probati } \\
\text { on services, } \\
\text { LAs }\end{array}$ & $\begin{array}{l}\text { The development of detailed } \\
\text { perpetrator profiles } \\
\text { The implementation of } \\
\text { primary and secondary } \\
\text { school-based interventions } \\
\text { that included the inclusion of } \\
\text { cross-curricular content in } \\
\text { drama and English course } \\
\text { work, amongst others, with } \\
\text { the success of the } \\
\text { intervention enhanced when } \\
\text { curriculum was } \\
\text { collaboratively developed. }\end{array}$ & $\begin{array}{l}\text { Surveys and/or interviews } \\
\text { with domestic violence } \\
\text { perpetrators } \\
\text { Interviews with a wide } \\
\text { range of agencies and } \\
\text { organisations across the } \\
\text { Northumbria police force } \\
\text { area } \\
\text { Secondary data gathering } \\
\text { including but not limited } \\
\text { to accessing project case } \\
\text { files; project databases } \\
\text { and monitoring sheets; } \\
\text { project visits and } \\
\text { observations; }\end{array}$ & $\begin{array}{l}\text { - Perpetrators are predominantly male, over } \\
\text { the age of } 25, \text { the majority has children and were } \\
\text { in full-time employment at the time of the } \\
\text { interview. } \\
\text { - Most perpetrators on voluntary programs } \\
\text { report having had contact with the police and } \\
\text { other agencies because of DA } \\
\text { - "Trigger to change" appears when the } \\
\text { perpetrator perceives that normal state of affairs } \\
\text { fails to happen, when victim/survivor threaten to } \\
\text { leave, and when the perpetrator experiences a } \\
\text { profound sense of loss or anticipation of loss. } \\
\text { - Perpetrators are often aware of their } \\
\text { problematic behaviour, but fail to seek help } \\
\text { - Accommodation for perpetrators is an } \\
\text { important factor in avoiding further harm to } \\
\text { victims/survivors and children. }\end{array}$ \\
\hline $\begin{array}{l}\text { Lea and } \\
\text { Callaghan } \\
2016\end{array}$ & Peer & Tertiary & $\begin{array}{l}\text { Community } \\
\text { based } \\
\text { advocacy } \\
\text { services; } \\
\text { statutory } \\
\text { services. }\end{array}$ & $\begin{array}{l}\text { Community-based } \\
\text { advocacy service } \\
\cdot \quad \text { Risk assessment, needs } \\
\text { assessment, information } \\
\text { provision and education, } \\
\text { empowering decision- } \\
\text { making, legal advice, } \\
\text { referrals to other services as } \\
\text { required. }\end{array}$ & $\begin{array}{l}\text { 1. Case file analysis } \\
\text { 2. Surveys } \\
\text { 3. Interviews with } \\
\text { victims and key } \\
\text { individuals in statutory } \\
\text { and community } \\
\text { organisations }\end{array}$ & $\begin{array}{l}\text { - Intervention successful in providing } \\
\text { responsive, needs driven service for survivors } \\
\text { - } \quad \text { Service perceived by both service users } \\
\text { and agency stakeholders as excellent. } \\
\text { - Victims found the service to be accessible } \\
\text { and efficient, felt validated and listened to, and } \\
\text { understood all the options available to them and } \\
\text { their implications. They also reported benefits in } \\
\text { terms of outcomes achieved and attained a sense } \\
\text { of control. } \\
\text { - Provision of an advocate with a } \\
\text { background in law and specialist training in } \\
\text { domestic abuse enabled a rounded service. - } \\
\text { - Victims reported that they developed } \\
\text { personal resources to act more swiftly to report } \\
\text { abuse and to avoid abusive relationships in the } \\
\text { future. }\end{array}$ \\
\hline
\end{tabular}




\begin{tabular}{|c|c|c|c|c|c|c|}
\hline $\begin{array}{l}\text { Citation } \\
\text { reference }\end{array}$ & $\begin{array}{l}\text { Grey lit. or } \\
\text { Peer- } \\
\text { reviewed }\end{array}$ & $\begin{array}{l}\text { Level of } \\
\text { intervention }\end{array}$ & $\begin{array}{l}\text { Agencies } \\
\text { involved }\end{array}$ & Interventions & Evaluation measures & Summary of findings \\
\hline Lee 2014 & Grey & Tertiary & $\begin{array}{l}\text { Police; Third } \\
\text { sector agency } \\
\text { specialising } \\
\text { in DA }\end{array}$ & $\begin{array}{ll}\cdot & \text { Prevention training } \\
\cdot & \text { Workshops } \\
\cdot & \text { Victim contact } \\
\cdot & \text { Hampton Trust } \\
\cdot & \text { Hampshire } \\
\text { Constabulary, Caution } \\
\text { Against Relationship Abuse } \\
\text { (CARA) }\end{array}$ & $\begin{array}{ll}\text { 1. } & \text { Questionnaires } \\
\text { 2. } & \text { Interviews } \\
\text { 3. } & \text { Partner feedback }\end{array}$ & $\begin{array}{l}\text { - Program highly effective at increasing } \\
\text { awareness of what constitutes DA and impacts of } \\
\text { abusive behaviour on children and partners. } \\
\text { - } \quad \text { Program effective at changing attitudes } \\
\text { towards partners and relationships, and some } \\
\text { changes in behaviour } \\
\text { - Staff delivering interventions and } \\
\text { programs for use with individuals engaging in } \\
\text { abusive behaviour need to be both highly skilled } \\
\text { and experienced to ensure participant } \\
\text { engagement. }\end{array}$ \\
\hline Part 2006 & Peer & Tertiary & $\begin{array}{l}\text { Tayside } \\
\text { Police and } \\
\text { Barnardo's }\end{array}$ & $\begin{array}{l}\text { Legal, financial, housing, } \\
\text { education, psychological help } \\
\text { and support for } \\
\text { victims/survivors }\end{array}$ & $\begin{array}{l}\text { 1. Interviews and } \\
\text { questionnaires of project } \\
\text { workers, police and } \\
\text { service users }\end{array}$ & $\begin{array}{l}\text { - Most effective interventions are individually } \\
\text { adjusted to needs without time constraint, } \\
\text { includes help and support to family, concentrates } \\
\text { on building self-esteem and confidence while } \\
\text { supporting autonomous decision making }\end{array}$ \\
\hline $\begin{array}{l}\text { Peckover et } \\
\text { al } 2013\end{array}$ & Grey & Tertiary & $\begin{array}{l}\text { WomenCentr } \\
\text { e and the } \\
\text { Foundation } \\
\text { for Families; } \\
10 \text { Local } \\
\text { Safeguarding } \\
\text { Children } \\
\text { Boards }\end{array}$ & $\begin{array}{l}\cdot \text { Advocacy, support and } \\
\text { recovery } \\
\cdot \quad \text { The Women Centre } \\
\text { and Domestic Violence Pilot } \\
\text { training programme } \\
\cdot \quad \text { Risk assessment, and } \\
\text { risk reduction }\end{array}$ & $\begin{array}{l}\text { 1. Telephone } \\
\text { interviews with project } \\
\text { participants } \\
\text { 2. Observations of } \\
\text { key stakeholder meetings } \\
\text { and of secondary data } \\
\text { sources } \\
\text { 4. Case mapping } \\
\text { 3. Semi-structured }\end{array}$ & $\begin{array}{l}\text { - Multi-agency working in DA is complex } \\
\text { and could be improved } \\
\text { - Professional differences exist relating to } \\
\text { risk, priorities, understanding, and approach to } \\
\text { DA should be recognised and considered within a } \\
\text { multi-agency context. } \\
\text { - Case mapping should be considered in } \\
\text { relation to safeguarding practices and processes. } \\
\text { - DA is often minimised }\end{array}$ \\
\hline
\end{tabular}




\begin{tabular}{|c|c|c|c|c|c|c|}
\hline $\begin{array}{l}\text { Citation } \\
\text { reference }\end{array}$ & $\begin{array}{l}\text { Grey lit. or } \\
\text { Peer- } \\
\text { reviewed }\end{array}$ & $\begin{array}{l}\text { Level of } \\
\text { intervention }\end{array}$ & $\begin{array}{l}\text { Agencies } \\
\text { involved }\end{array}$ & Interventions & Evaluation measures & Summary of findings \\
\hline $\begin{array}{l}\text { Peckover \& } \\
\text { Golding } \\
2015\end{array}$ & Peer & Tertiary & & & $\begin{array}{l}\text { interviews with } \\
\text { stakeholders } \\
\text { 4. Online survey with } \\
\text { training attendees }\end{array}$ & $\begin{array}{l}\text { - Practitioners may focus on other } \\
\text { presenting problems such as substance abuse } \\
\text { rather than DA } \\
\text { - Multi-agency approach may result in } \\
\text { dilution of client presentation in terms of } \\
\text { understanding, assessment, intervention and } \\
\text { evaluation of DA } \\
\text { - The role of women's specialist services in } \\
\text { multi-agency DA work is often marginalised }\end{array}$ \\
\hline $\begin{array}{l}\text { Stanley et al } \\
2010\end{array}$ & Grey & Tertiary & $\begin{array}{l}\text { Police; } \\
\text { independent } \\
\text { domestic } \\
\text { violence } \\
\text { advocates } \\
\text { (IDVA) } \\
\text { services; } \\
\text { children's } \\
\text { social } \\
\text { services; } \\
\text { local } \\
\text { safeguarding } \\
\text { children } \\
\text { boards }\end{array}$ & $\begin{array}{l}\cdot \text { Police interventions in } \\
\text { DA involving children } \\
\cdot \quad \text { Children's social } \\
\text { services interventions } \\
\cdot \quad \text { Communication and } \\
\text { notification of information to } \\
\text { child protection services and } \\
\text { subsequent filtering and } \\
\text { service response across } \\
\text { agencies }\end{array}$ & $\begin{array}{l}\text { 1. Consultation with: } \\
\text { young people, survivors } \\
\text { and perpetrators } \\
\text { 2. Consultation with } \\
\text { expert stakeholders and } \\
\text { professionals } \\
\text { 3. Survey of } \\
\text { innovative professional } \\
\text { practice }\end{array}$ & $\begin{array}{l}\text { - Changing knowledge and attitudes more } \\
\text { effective than behavioural change } \\
\text { - Young people report being excluded or } \\
\text { ignored when police intervened in domestic } \\
\text { violence incidents. } \\
\text { - In majority of the cases, the perpetrators } \\
\text { are removed when police are called out to a } \\
\text { domestic violence incident. } \\
\text { - Police notifications triggered intervention } \\
\text { at the level of an initial assessment from } \\
\text { children's social services in only } 5 \% \text { of sample } \\
\text { cases. } \\
-\quad \text { Discrepancies between service agencies } \\
\text { lead to additional work for social workers and a } \\
\text { lack of understanding of children's experiences } \\
\text { of DA. } \\
\text { - Both police workers and social workers } \\
\text { report that inter-professional training on DA } \\
\text { could enhance understanding of each other's } \\
\text { roles }\end{array}$ \\
\hline
\end{tabular}




\begin{tabular}{|c|c|c|c|c|c|c|}
\hline $\begin{array}{l}\text { Citation } \\
\text { reference }\end{array}$ & $\begin{array}{l}\text { Grey lit. or } \\
\text { Peer- } \\
\text { reviewed }\end{array}$ & $\begin{array}{l}\text { Level of } \\
\text { intervention }\end{array}$ & $\begin{array}{l}\text { Agencies } \\
\text { involved }\end{array}$ & Interventions & Evaluation measures & Summary of findings \\
\hline Stanley 2011 & Peer & Tertiary & $\begin{array}{l}\text { Police; } \\
\text { independent } \\
\text { domestic } \\
\text { violence } \\
\text { advocates } \\
\text { (IDVA) } \\
\text { services; } \\
\text { children's } \\
\text { social } \\
\text { services; } \\
\text { local } \\
\text { safeguarding } \\
\text { children } \\
\text { boards }\end{array}$ & $\begin{array}{l}\cdot \text { Referrals from social } \\
\text { services to voluntary or } \\
\text { health services } \\
\cdot \quad \text { Regular interagency } \\
\text { meetings to screen } \\
\text { notifications } \\
\cdot \quad \text { Applying police risk- } \\
\text { assessment procedures or } \\
\text { protocols to route families } \\
\text { towards services after a DA } \\
\text { incident. } \\
\cdot \quad \text { Developing a risk } \\
\text { assessment tool that focuses } \\
\text { on the child in the DA } \\
\text { scenario }\end{array}$ & $\begin{array}{l}\text { 1. Consultation with } \\
\text { expert stakeholders and } \\
\text { professionals including } \\
\text { local safeguarding } \\
\text { children boards } \\
\text { 2. Analysis of case data } \\
\text { from police and social } \\
\text { services records }\end{array}$ & $\begin{array}{l}\text { - Police notifications triggered intervention } \\
\text { at the level of an initial assessment from } \\
\text { children's social services in only 5\% of sample } \\
\text { cases. } \\
\text { - Discrepancies between service agencies } \\
\text { lead to additional work for social workers and a } \\
\text { lack of understanding of children's experiences } \\
\text { of DA. } \\
\text { - Both police workers and social workers } \\
\text { report that inter-professional training on DA } \\
\text { could enhance understanding of each other's } \\
\text { roles }\end{array}$ \\
\hline $\begin{array}{l}\text { Stanley } \\
2015\end{array}$ & Peer & $\begin{array}{l}\text { Primary, } \\
\text { Secondary } \\
\text { and Tertiary }\end{array}$ & & $\begin{array}{l}\text { School-based } \\
\text { interventions delivered by } \\
\text { teachers or DA specialists } \\
\cdot \quad \text { Health service } \\
\text { professional referrals to } \\
\text { social services after } \\
\text { appropriate training } \\
\cdot \quad \text { Strategies suggested to } \\
\text { streamline information } \\
\text { sharing } \\
\cdot \quad \text { Multi-agency responses } \\
\text { and whole-system approaches }\end{array}$ & $\begin{array}{l}\text { 1. Systematic review } \\
\text { of international and peer- } \\
\text { reviewed literature with } \\
\text { focus on the UK }\end{array}$ & $\begin{array}{l}\text { - Policy frameworks should incentivize } \\
\text { multi-agency working } \\
-\quad \text { Neutral leadership and buy-in across } \\
\text { multiple agencies is important } \\
\text { - Co-location and inter-agency training are } \\
\text { shown to work well }\end{array}$ \\
\hline $\begin{array}{l}\text { Stanley \& } \\
\text { Humphreys } \\
2014\end{array}$ & Peer & Tertiary & $\begin{array}{l}\text { Myriad } \\
\text { service and } \\
\text { IDVA } \\
\text { agencies }\end{array}$ & $\begin{array}{l}\text { Involving children in } \\
\text { risk assessments } \\
\cdot \quad \text { Developing a risk } \\
\text { assessment tool that focuses } \\
\text { on the child in the DA } \\
\text { scenario } \\
\cdot \quad \text { Strategizing for best } \\
\text { practices in multi-agency } \\
\text { information sharing }\end{array}$ & $\begin{array}{l}\text { 1. Systematic review } \\
\text { of international published } \\
\text { literature and UK grey } \\
\text { literature }\end{array}$ & $\begin{array}{l}\text { - } \quad \text { Necessary for agencies to develop } \\
\text { common assessment tools } \\
\text { - Need to improve balance between } \\
\text { assessment of risk and the delivery of services to } \\
\text { children and families } \\
\text { - Co-location is a recommended approach } \\
\text { - Multi-agency approaches should not } \\
\text { exclude children and women survivors in risk } \\
\text { assessment and management }\end{array}$ \\
\hline
\end{tabular}




\subsection{Results of the Review}

Projects which implemented multi-agency approaches varied in terms of strategies used but tended to include the addition of a focal point, person or organisation to coordinate responses across agencies. This included co-location of independent domestic violence advocates (IDVAs) (Granville \& Bridge 2010, Coy \& Kelly 2011, Peckover et al 2013, Peckover \& Golding 2015), the establishment of a hub to coordinate multi-agency working (Donovan et al 2010, Donovan \& Griffiths 2015), allocation of advocacy workers (Clarke \& Wydall 2013), a comprehensive community outreach service (Hague and Bridge 2007) and colocation of a support workers in police stations (Part 2006). Studies that evaluated interventions with health professionals were largely to encourage routine enquiry and raise awareness of domestic abuse amongst doctors, midwives and nurses, which were classified as variable secondary or tertiary preventative measures, depending on the evaluation focus.

In the section below, early intervention strategy evaluations are sorted into one of 6 areas that characterise the main objectives of the evaluation study. Some of these category boundaries are blurred as well, for example, when evaluations include studies that might be identified within two separate areas. The evaluations have nonetheless been categorised according to its dominant characteristic, which was discernible in all cases.

\subsection{Primary Prevention}

\subsubsection{School-based preventative initiatives}

In our review of primary preventions, it was found that there was a dominant emphasis on schools-based interventions. In the following discussion the evaluations by Fox et al (2014), Fox et al (2016), Hale et al (2012), Hester and Westmarland (2005), Stanley et al (2015) are 
discussed.

Raising awareness of domestic abuse and equipping pupils with the necessary skills required to build relationships based on mutual respect and understanding was a core or partial aim of three of the projects evaluated by Hester and Westmarland (2005). The projects employed different approaches including drama, the development of a teaching package and delivery of teaching sessions developed as part of schools' personal, social and health education (PSHE) curriculum. Findings from Hester and Westmarland's (2005) evaluation indicate that pupils particularly valued interventions that were student-centred, interactive, and used visual input such as drama. Training for teachers and multi-agency support was important and crosscurricular approaches (for example in PSHE) reinforced the positive programme impacts.

Fox et al (2016) evaluated the 'Relationships Without Fear' programme. Children from seven schools that had agreed to participate in the programme were matched with pupils from schools not receiving the programme. Fox et al (2016) found that boys and girls who had received the intervention became less accepting of domestic abuse and more likely to seek help compared with those in the control group even 3-months after the intervention Outcomes did not vary by self-reported experiences of abuse.

Likewise, Hale et al (2012) and Fox et al (2014) found that school-based programmes can increase knowledge, although some young people misunderstood issues related to domestic abuse, especially the role of power and control within relationships with misconceptions and gender differences evident. Hale et al (2012) found that boys are generally less engaged in domestic abuse prevention programmes, proposing that this is due to how [male] perpetrators are represented in teaching materials and the tendency for sessions to start with a lesson / message that young boys already know, namely, that violence is wrong. Stanley et al (2015) propose that while off-the-shelf programmes are valuable, there should also be provision for 
local elements in programme design and content with co-production (involving teachers and pupils) in design and implementation of programmes recommended (Hale et al 2012, Fox et al 2014, Stanley et al 2015).

Hester and Westmarland (2005) report that multi-agency support for teachers was consistently cited as an important element of success in the projects' preventative education strand, with multi-agency provision providing access to resources and expertise that would not otherwise have been available. In contrast, Stanley et al (2015) found key differences between teachers' perspectives and those working in domestic abuse services regarding the desired outcomes from school-based training programmes. Teachers tended to focus on attitude change, on the basis that children were exposed to wide range of influences outside of school, while the goals of domestic abuse sector workers were more focused on changing behaviour. Education professionals were more likely to see measures of wellbeing or outcomes pertaining to help-seeking as more appropriate measures of success.

\subsection{Secondary and Tertiary Prevention}

Secondary prevention is concerned with stopping abuse once it has occurred, with the aim of intervening as early as possible to achieve this goal. The review revealed that a range of initiatives have been tested to determine their effectiveness in early identification and prevention of escalation. Multi-agency working provided both benefits and challenges for the early identification and prevention of domestic abuse. The different strategies adopted are outlined below.

\subsubsection{Information sharing}

In the following discussion on barriers in the realm of information sharing, the following evaluations are discussed: Coy \& Kelly (2011), Peckover \& Golding (2015), Stanley et al 
(2010), Stanley et al. (2011) and Stanley \& Humphreys (2014).

Across prevention strategies, information sharing has been found to be problematic both in terms of what data is collected (Hester \& Westmarland 2005), how information is shared across agencies (Coy \& Kelly 2011) and how risk is appraised (Coy \& Kelly, 2011, Stanley et al 2011). In addition, due to the volume of notifications between police and social services, information sharing between these agencies can inhibit the ability of practitioner to locate and identify those most at risk (Stanley et al 2011).

For example, in Coy \& Kelly's (2011) evaluation of four independent domestic violence advocate (IDVA) schemes established in London it was apparent that the schemes did not share a common definition/understanding of domestic abuse. Assumptions were made about what happened to shared information and about how much information was needed. For example, Stanley et al (2010) found that police officers mistakenly assumed that, when receiving a referral, social services would have access to a full police report and were surprised that only $15 \%$ of notifications from police received social work assessment and intervention. They also observed that "the notifications sent to children's social services did not consistently convey all information available to the police that might have been valuable for social workers, and, in some cases, information was omitted about the involvement of children in incidents and the seriousness of an incident that might have impacted on children's social services' response to notifications" (Stanley et al 2010: 249). There were also numerous examples of information being lost and errors being introduced in the transfer of information from one system to another.

Stanley \& Humphreys (2014) and Peckover \& Golding (2015) noted that in cases of domestic abuse and child safeguarding, different levels of risk emerged at different times for police, social services and IDVAs, and that these agencies may interpret them differently depending 
on whether their primary focus is the adult victim, perpetrator or child. Separation from an abusive partner is regarded as a heightened risk factor by the police and IDVAs but may conversely be the goal of intervention in child protection (Stanley et al., 2011). Stanley et al's (2010) study found that police risk assessments focused on adult victims and perpetrators to the exclusion of children, resulting in police providing incomplete information to social services. It is therefore evident that different focuses may lead to difficulties in developing unified approaches in lower-risk cases.

\subsubsection{Routine Enquiry by Health Professionals}

In the following discussion on the practices of routine enquiry by health professionals, the following evaluations are discussed: Feder et al (2011) and Bacchus et al (2010).

Historically, health professionals have not routinely enquired about domestic abuse; rather, their approach has been selective enquiry based on likely assessment of the presence of domestic abuse (Taket 2004). Although rates of identification from screening interventions are low when compared to best estimates of prevalence of such violence, routine enquiry by health professionals can enable victims to access support services (O'Doherty et al 2014).

In a randomised controlled trial, Feder et al (2011) found a sevenfold increase in referrals by general practitioners to an advocacy service following a training intervention, the training intervention delivered in acknowledgement that health professionals feel ill-equipped to implement routine enquiry. However, training interventions do not always produce sustained increases in routine enquiry. Bacchus et al (2010) evaluated an intervention in maternity and sexual health services which involved the introduction of domestic violence clinical guidelines, and a rolling programme of one-day domestic violence training which included mechanisms for referral to an on-site domestic violence advocacy service. The authors found that although the training resulted in changes in health professionals' knowledge and practice 
in the short-term, it did not result in universal routine enquiry; six-months post-training, routine enquiry had not been universally implemented. Over three quarters of the midwives reported difficulties in achieving routine enquiry, citing the presence of partners or relatives during the consultation as a barrier, as was women's mistrust of health professionals and concomitant reluctance to engage. Language barriers and time constraints were also reported as barriers to implementation (Bacchus et al 2010).

\subsubsection{Routine Enquiry and Co-Location of Services}

In the following discussion on the practices of routine enquiry as connected to co-location of services, the following evaluations are discussed: Coy \& Kelly (2011), Evans and Feder (2014) and Part (2006).

As Peckover and Golding (2015:3) note, multi-agency working includes work undertaken by different professionals with the same client and/or family, often requiring information sharing, co-ordination of service provision and joint visiting and/or assessment. To this end good working relationships and communication are central to successful multi-agency working. It follows therefore that geography, i.e. proximity of services, may improve multiagency working.

Findings from the review indicate that co-location of services promotes routine enquiry and onward referral. In an evaluation of a domestic abuse intervention project in Tayside, Part (2006) detailed how staff support workers from Barnardo's shared offices with Tayside Police's domestic abuse support officer. This resulted in all police officers automatically following up all recorded incidents of domestic abuse. Service users reported consistency, approachability and individualised responses with long-term support offered based on 
individual needs rather than finite time or risk-based frameworks, helping service users build self-esteem or take 'life-saving' decisions to leave abusive relationships. However, half of the respondents had already been experiencing abuse for more than five years with others only engaging weeks or months after initial contact, illustrating that early intervention may be a long-term process that is reliant on both detection and engagement from service users who may face multiple intrapersonal and interpersonal barriers to help-seeking (Evans and Feder, 2015).

Coy \& Kelly’s (2011) evaluation of four London based independent domestic violence advocate (IDVAs) schemes were co-located in a police station, a community based charity providing an advocacy service, a community based women's organisation providing holistic services for victims of gender-based violence, and an accident and emergency department. The co-location of the IDVAs facilitated routine enquiry and follow-up resulted in increased detection and decreased number of repeat cases (Coy and Kelly 2011). Similarly, routine enquiry within a Manchester maternity hospital and referral to a co-located IDVA was shown to support early intervention during pregnancy, enhancing the confidence of midwives to enquire about domestic abuse and resulting in increased onward referrals by midwives (Granville \& Bridge, 2010).

\subsubsection{Partnership Projects}

In the following discussion on the practices of partnership projects, the following evaluations are discussed: Hague \& Bridge (2008) and Donovan et al (2010). Both projects displayed elements of both secondary and tertiary strategies, a strength that resulted from the nature of partnered work.

An evaluation of the Cheshire Domestic Abuse Project (Hague \& Bridge, 2008) found that coordinated multi-agency working was key to early intervention and inter-professional 
understanding. Over $70 \%$ of victims reported reduced risk after exiting the service. The project involved police, social services and local voluntary services and provided a singlepoint of access for victims and families of domestic abuse with police referral occurring immediately after a domestic abuse incident. Involvement with the project enabled police officers to gain greater understanding of the difficulties faced by victims when going to court and when accessing the different departments involved in responding to domestic abuse. Police also felt that with early and consistent advocacy and intervention, victims received better information and were less disillusioned by the court process (Hague \& Bridge, 2008).

These partnerships were more than just multi-agency working partnerships and displayed particularly collaborative interactions and service provision. For example, Donovan et al (2010) evaluated two multi-agency partnership projects in the North of England. The projects were established to develop domestic abuse services for early intervention 'at the point of crisis'. The projects offered referral within 24 hours of a police force reported incident, tailored one-to-one practical and emotional support to victim/survivors and children, as well as voluntary perpetrator programmes. Evaluation and comparison of both projects identified several indicators of success. Improved outcomes for service users included risk reduction, increased self-recognition of abuse, improved health and wellbeing and confidence in future help seeking. Engagement with services was shown to reduce the likelihood of repeat referrals. Donovan et al (2010) suggest this resulted in sustained risk reduction, as well as higher engagement rates for those assessed at standard and medium risk, indicating that further escalation may have been prevented. The role of specialist domestic violence workers in each service were also found to be vital to coordinating work between partner agencies and maintaining consistency for victims. The authors cited emotional support by many services users as one of the most significant elements, echoing the findings of Part (2006), and indicating that prompt, holistic and individualised responses may be important elements in 
early intervention work.

\subsubsection{Advocacy}

In the following discussion on the practices of advocacy, the following evaluations are discussed: Granville \& Bridge (2010), Hague \& Bridge (2008), Lea and Callaghan (2016), and Part (2006).

This review of the literature found that the use of independent domestic violence advocates (IDVAs) and other advocacy services were highly valued by service users and professionals and therefore have a significant potential to enable early interventions. As noted above, the co-location of IDVAs in various statutory agencies was highly valued for the provision of individual support based on individual need (Part 2006). The co-location of an IDVA service in a Manchester maternity hospital resulted in an improvement in the safety of women and children accessing the maternity service, enabling early intervention with women experiencing domestic abuse in pregnancy (Granville \& Bridge 2010). The project also increased midwives' rates of routine enquiry as working with IDVAs enabled them to become more competent in recognising and responding to domestic abuse (Granville \& Bridge 2010).

The literature reviewed suggests that victims accessing advocacy projects value being able to obtain legal, financial, housing and education support, thus representing a 'whole package' of support (Part 2006). Lea and Callaghan's (2016) evaluation of a community-based advocacy domestic abuse service found the holistic model of legal, practical, mental health related and advocacy components of the service resulted in a range of benefits for victims, while also enhancing multi-agency working. These findings were also evident in the evaluation of the Chester Domestic Abuse Project (Hague \& Bridge 2008). Hague \& Bridge (2008) propose that one of the key elements of success for this project was the comprehensive early 
intervention/outreach service and avoidance of criminal justice responses in favour of wide ranging community services, including health and education.

\subsubsection{Responses to perpetrators}

In the following discussion on the practices of advocacy, the following evaluations are discussed: Clarke and Wydall (2013), Donovan et al 2010, Donovan and Griffith (2015) and Lee (2014). These programmes were all focused on preventing perpetrator recidivism and supporting victims so were tertiary in nature. However, they all attempted to address the perpetrators from a preventative point of view, rather than a criminal justice one, aiming to support perpetrators with enabling their access to housing and support services, as well as providing educational content on domestic abuse.

Programmes addressing perpetrator behaviour and recidivism exist but have received the least attention from a multi-agency perspective with limited evidence suggesting which programmes are the most effective. However, Donovan et al (2010) found that $35-40 \%$ of perpetrators were responsible for as many as $2 / 3$ of referrals to secondary support services, suggesting that reducing individual perpetrator recidivism may benefit multiple victims.

Donovan and Griffith's (2015) longitudinal evaluation of two projects found that voluntary perpetrator programmes were the least successful, marked by low referral and attrition, which was attributed by the authors to the fact that work with perpetrators was either not within the remit of agencies or was addressed from a criminal justice perspective rather than as an issue of partner or family member support. The authors also found that some female practitioners did not feel safe working directly with male perpetrators.

Clarke and Wydall (2013) studied 'Making Safe', a project that re-housed perpetrators of domestic abuse with key-worker support, allowing victims to remain in their own homes. The response involved statutory and voluntary sector agencies, including the police, probation, 
housing and specialist domestic abuse services. Findings from the evaluation suggest that an integrated approach to victims and perpetrators helped to develop individualised plans to keep victims and their families safe, with key workers able to keep perpetrators under surveillance as well as support them. Clarke and Wydall (2013) suggested however that there were tensions between those professionals who worked with perpetrators and those who worked with victims over the allocation of resources and service provision.

Hampshire police devised 'Caution Against Relationship Abuse' (CARA) a behavioural change programme for those committing minor domestic violence offences and who have little to no prior offences in their history. In the programme, offenders were offered the option to receive a conditional caution and attend a 'Domestic Abuse Awareness Raising Course' (DAARC). The programme also directed perpetrators to additional support, e.g. drug/alcohol or mental health services. Early findings indicate that those who attended behavioural change workshops were $46 \%$ less likely to re-offend than those who didn't (Lee, 2014). Although this represents a slim metric of success, the finding does provide evidence to support early intervention with perpetrators and suggests that a first non-violent offence may provide a window of opportunity for behaviour change (Lee, 2014).

\subsection{Discussion}

The findings from this review demonstrate the range of interventions that have been implemented across the UK and confirm that multi-agency working takes many different forms. Clearly, domestic abuse provision does not adhere to one single model (McInnes \& Newman, 2006) making comparison complex (Atkinson et al, 2007; Home Office, 2014b).

This review indicates that universal early intervention programmes based in schools can 
influence children's attitudes towards and knowledge of domestic abuse (NICE, 2013; Hale et al, 2012) and evidence supports the suggestion that intervention programmes designed with the involvement of children and teachers are more successful (Stanley et al, 2015; Hale et al, 2012). However, there is little evidence-based guidance available to help schools determine what works best and for whom (Fox et al 2016, Fox et al 2014; Guy et al 2014; Hester \& Westmarland, 2005; Stanley et al, 2015).

Multiple partnerships were shown to be effective in building a coordinated community response to domestic abuse (Hague and Bridge 2008), the most significant element of which was the comprehensive early intervention outreach / advocacy service. This service avoided concentrating principally on criminal justice responses by incorporating a wide range of community-based and women-centred interventions, as did other advocacy interventions that tended to adopt a more holistic approach (Part 2006, Lea \& Callaghan 2016). Locating interventions within an advocacy rather than criminal justice framework has the potential to encourage victims to report abuse (Harvie \& Mazie 2011) and to this end the review suggests that advocacy services may facilitate an intervention to be initiated at an earlier stage.

Donovan et al's (2010) comparative evaluation work, although lacking long-term follow up to assess ongoing risk or outcomes for service users, provides useful insights into the processes of effective multi-agency working. The 'LetGo' project, based in Cumbria, established more effective multi-agency working, which was attributed to multiple developmental factors including partnership working, resources, communication and power relations. Cumbria could respond more successfully to challenges because of strong existing relationships across partner agencies, clarity of role and shared ownership between agencies. This contrasted with the Gateshead project which faced challenges with communication between and within partner agencies, including lack of shared understanding of project 
objectives and each agency's role. Service level agreements and information sharing protocols between partner agencies, engagement of senior management and establishing inclusive multi-agency working relationships were also problematic. The Chester Domestic Abuse Partnership Project (Hague \& Bridge 2007) included health and education agencies from the beginning, factors which were also indicators of success in Donovan et al's (2010) evaluation of the 'Gateshead Project. However, there is evidence that many multi-agency relationships relied on 'goodwill' of individuals and their specific contacts rather than a whole agency response (Coy \& Kelly 2011)

\subsection{Barriers to multi-agency working}

The barriers to multi-agency working that are apparent in the wider literature (Atkinson et al 2001, Secker \& Hill 2001) include difficulties in information sharing, communication, and differing responses to risk, as apparent in the papers included in this review. For example, (Coy \& Kelly 2011) describe how independent domestic violence advocates faced challenges in negotiating the field of multi-agency responses, which they referred to as resembling 'turf wars' (2). Peckover \& Golding (2015) found professional differences in how cases are understood and managed, particularly in relation to risk, reflecting barriers that have also been encountered in general practice (Yeung et al 2012). Professional differences were also shown to manifest in problems in how cases were understood and managed, particularly in relation to 'risk', as well as in the pursuit of different professional priorities. Differences also appeared in the varying approaches to working with families, which must be recognised, considered and managed within a multi-agency context.

Other barriers resulted from conflicting ideas about the identities of the agencies and their professional priorities in relation to others. For example, police officers assess risk through a criminal justice perspective, their primary role being to protect the public and remove the 
offender, while probation services will be concerned with risk of the perpetrator re-offending (Peckover \& Golding 2015). On the other hand, IDVAs and women's groups, such as refuges, tend to adopt an advocacy/victim support viewpoint, but may also be positioned as 'marginal players' when working alongside more established institutions (Harris 2003). As observed in the Gateshead and Cumbria projects (Donovan et al 2010, Donovan \& Griffiths 2015), practitioners working in children's services claimed to work with families but actually only worked with mothers and children. In contrast, health professionals considered the family through the lens of their patient. Different practitioners had different approaches to individuals and as well as various perceptions of how they work within and across teams and agencies (O’Carroll et al 2016).

Hymans (2008) proposes that differences across all agencies are initiated and promoted by professional knowledge and training. Training initiatives reported in the review tended to be intra-agency (Bacchus et al 2010, Feder et al 2011, Yeung et al 2012, Hale et al 2012, Fox et al 2014) thereby re-enforcing existing social and professional identity, professional culture and inter-professional hierarchies, factors that can influence attitudes to multi-agency working (O’Carroll et al 2016). The benefits of inter-professional training have been widely explored in healthcare settings (Cleaver et al, 2008; Reeves et al, 2010; Stanley et al 2010), but there has been less research as to its efficacy in relation to domestic abuse and early intervention. Some research indicates that individual roles and responsibilities may impact confidence in handling cases and require variations in skills that all practitioners may not possess in equal measures (Yeung et al, 2012). This suggests that the heterogeneous needs of practitioners as well as service users should be recognised when designing training and expanding practises of routine enquiry around domestic abuse. 


\subsection{Limitations to the study}

The extent to which the schemes reviewed can be classified as early intervention approaches is debatable as all schemes, bar the school initiatives, represented interventions that occurred once domestic abuse had been reported.

Other limitations include the geographical parameters of the study, which was confined to the UK. This circumscribed approach excluded some known key evaluation literature in the field, for example Edlseon \& Malik's (2008) US based multiagency evaluation, but allowed for other insights related to regional specificity. For example, in controlling for national boundaries, the papers in this review can be considered to all reflect the operation of multiagency partnerships under the same legal infrastructure. Differences in legal and policy frameworks provide a scaffolding upon which cultural and societal norms are created and contested. It would have been challenging to compare service provision across national boundaries without a consideration of how variations in national service provision policies, and the differences in stakeholders involved, shape the success or failure of different early interventions. For example, the Greenbook multi-agency evaluation took place in an American context and included stakeholders such as dependency courts that do not exist in the UK. In the interest of making a statement widely applicable to the UK that avoids this ambiguity of the effect of legal and policy variations, this strategy of reviewing UK literature only was adopted.

A further limitation is the degree to which our review shied away from studies that primarily centred the experiences of children. While international studies have found evidence of considerable overlap between child mistreatment and domestic abuse cases, the aim in this review is to look at domestic abuse victims through the two conflicting lenses of a feminist, women-centred approach and a criminal justice approach. Studies that centre the experience 
of the child introduce the need for other lenses not under consideration in this review. Local safeguarding children boards are present as stakeholders in several of these evaluations for the role they play in domestic abuse cases. Nonetheless, while other reviews such as the Greenbook review achieve a greater depth of focus on children, this study achieves a greater emphasis on the needs of victims to receive quality multi-agency level support in order to access services to improve outcomes for themselves as well as any dependents.

Finally, it should be noted that although women comprise most victims (NICE 2014, ONS, 2015), this limits the generalisability of findings to specific populations such as men and nonbinary people, as well as to vulnerable populations such as the disabled and older victims. 


\subsection{Conclusions}

Findings from the review suggest that approaches that adopt an advocacy rather than criminal justice framework may be more effective in encouraging victims to report abuse, thereby potentially enabling earlier interventions. Findings also indicate that whilst early intervention is reported as a well-established preventative strategy for promoting better outcomes, particularly for children and young people (Guy et al 2014), what constitutes early intervention needs further consideration. Several projects that were the focus of the evaluations reviewed, demonstrated success in working with victims and perpetrators, but while interventions may have been successfully initiated at an early stage, abuse had already occurred. It is evident therefore that early intervention in domestic abuse work is dependent on victims accessing services early; thus, while agencies may respond as soon as a victim comes forward/accesses support, the pattern of violence and abuse may well be entrenched, leading to longer term patterns not as amenable to early intervention strategies.

To this end secondary prevention is reliant on early intervention strategies which promote positive messages about accessing services as soon as possible, addressing potential stigma associated with disclosing domestic abuse, as well as perceptions of police, social workers and health professionals. Early intervention in domestic abuse requires a multi-agency approach which presents challenges, often due to differing priorities of the agencies involved,

Further research evaluating the contribution of co-located roles and routine enquiry/referral to improving detection and shortening periods of abuse is needed. Further research into integrated perpetrator and victim responses could also help to expand provision for perpetrators and demonstrate the additional benefits to victims. At a policy level, establishing protocols for anonymised data sharing between multiple agencies and standardised early 
intervention referral pathways at a local level could help to identify patterns of abuse and challenge different professional conceptions of risk. Analysis of multi-agency domestic abuse training programmes and the combination of disciplines involved would also provide insight into developing inter-professional education programmes; their limitations as well as benefits to multi-agency working were explored. 


\section{References}

Atkinson, M., Wilkin, A., Stott, A., Doherty, P., \& Kinder, K. (2001). Multi-agency working: A detailed study. Local Government Association.

Atkinson, M., Wilkin, A., Stott, A., Doherty, P., \& Kinder, K. (2002). Multi-Agency Working: A Detailed Study. (LGE Research Report 26) Slough: NFER.

Atkinson, M., Doherty, P., \& Kinder, K. (2005). Multi-agency working models, challenges and key factors for success. Journal of Early Childhood Research, 3(1), 7-17.

Atkinson, M., Jones, M., \& Lamont, E. (2007). Multi-agency working and its implications for practice: A review of the literature. CFBT Education Trust.

Banks, D., Landsverk J. and Wang K. (2008). Changing Policy and Practice in the Child Welfare System Through Collaborative Efforts to Identify and Respond Effectively to Family Violence. Journal of Interpersonal Violence (23)7, pp. 903-932.

Bacchus, L. J., Bewley, S., Vitolas, C. T., Aston, G., Jordan, P \& Murray, S. F.(2010). Evaluation of a domestic violence intervention in the maternity and sexual health services of a UK hospital. Reproductive Health Matters, 18(36), 147-157. doi:10.1016/S09688080(10)36526-8

Barran, D. (2015). 'Early intervention is key to reducing domestic abuse'. Journal of family health, 26(1), 30-31.

British Medical Association. (2014). Domestic Abuse: June 2007 (Updated September 2014).

Campbell, J, Laughon, K, Woods, A. (2006) Impact of intimate partner abuse on physical and mental health: how does it present in clinical practice? In Intimate Partner Abuse and Health Professionals: New Approaches to Domestic Violence (eds G Roberts, K Hegarty \& G Feder): 43- 60. Elsevier.

Chan, Y. C., \& Yeung, J. W. K. (2009). Children living with violence within the family and its sequel: A meta-analysis from 1995-2006. Aggression and violent behavior, 14(5), 313322.

Clarke, A., \& Wydall, S. (2013). 'Making safe': a coordinated community response to empowering victims and tackling perpetrators of domestic violence. Social policy and society, 12(3), 393-406.

Cleaver, H., Nicholson, D., Tarr, S. \& Cleaver, D. (2008). Child protection, domestic violence and parental substance misuse: Family experiences and effective practice. Executive summary. London, England: Jessica Kingsley Publishers. Available online at: http://dera.ioe.ac.uk/8820/7/child-protection-domesticviolence-parentalsubstance-misuse2_Redacted.pdf 
Coy, M., \& Kelly, L. (2011). Islands in the stream: An evaluation of four London independent domestic violence advocacy schemes. The Henry Smith Charity. Available online at: https://www.trustforlondon.org.uk/documents/103/IDVA-Summary-Report.pdf

Department of Health. (2010). Improving services for women and child victims of violence: The Department of Health action plan. London: Department of Health.

Donovan, C., Griffiths, S., Grove, N., Johnson, H., \& Douglass., J. (2010). Evaluation of early intervention models for change in domestic violence: Northern Rock Foundation Domestic Abuse Intervention Project, 2004-2009. Northern Rock Foundation. Available online at: http://www.nr-foundation.org.uk/downloads/DAI-full-evaluation-report.pdf

Donovan, C., \& Griffiths, S. (2015). Domestic Violence and Voluntary Perpetrator Programmes: Engaging Men in the Pre-Commencement Phase. British Journal of Social Work doi:10.1093/bjsw/bct182

Edleson, J. L., \& Malik, N. M. (2008). Collaborating for Family Safety. Journal of Interpersonal Violence, 23(7), 871-875.

Evans, M. A., \& Feder, G. S. (2014). Help-seeking amongst women survivors of domestic violence: a qualitative study of pathways towards formal and informal support. Health Expectations. 2016 Feb;19(1):62-73. doi: 10.1111

Feder, G., Agnew-Davies, R., Baird, K., Dunne, D., Eldridge, S., Griffiths, C., Gregory, A., Howell, A., Johnson, M., Ramsay, J., Rutterford, C \& Sharp, D. (2011). Identification and referral to improve safety (IRIS) of women experiencing domestic violence with a primary care training and support programme: a cluster randomised controlled trial. The Lancet, 378, 1788-1795. DOI:10.1016/S0140- 6736(11)61386-X

Fox, C. and Butler, G. (2004). 'Partnerships: where next?' Community Safety Journal (3)3, $36-44$.

Fox, C,L., Hale, R., \& Gadd, D. (2014). Domestic abuse prevention education: listening to the views of young people. Sex Education ,14(1) 28-41. doi:10.1080/14681811.2013.816949

Fox, C. L., Corr, M. L., Gadd, D., \& Sim, J. (2016). Evaluating the effectiveness of domestic abuse prevention education: Are certain children more or less receptive to the messages conveyed?. Legal and Criminological Psychology. 21(1):212-227

Gasper, M. (2010). Multi-agency working in the early years: Challenges and opportunities. Sage Publications.

Granville, G. \& Bridge, S. (2010). PATHway Project: An Independent Domestic Violence Advisory service at St Mary's Maternity Hospital, Manchester: Independent Evaluation: Final Report. Available online at http://www.endthefear.co.uk/wpcontent/uploads/2010/10/PATHway-Project-Final-Report1.pdf?b40612

Greenhalgh, T. (2014). How to read a paper: the basics of evidence-based medicine. John Wiley \& Sons. 
Guy, J., Feinstein, L \& Griffiths, A. (2014). Early Intervention in Domestic Violence and Abuse. The Early Intervention Foundation. Available online at

https://www.eif.org.uk/files/pdf/early-intervention-in-domestic-violence-and-abuse-fullreport.pdf.

Hague, G \& Bridge, S. (2008). Inching forward on domestic violence: the 'co-ordinated community response' and putting it in practice in Cheshire. Journal of Gender Studies, 17(3), 185-199. doi: 10.1080/09589230802204134

Hale, B., Fox, C., \& Gadd, D. (2012). Evaluation of three European schools-based domestic violence prevention education programmes: First evaluation report: November 2012. Available online at:

http://www.keele.ac.uk/readapt/sites/default/files/documents/First\%20Complete\%20Research \%20Report.pdf. Last accessed February 2017

Hester, M., \& Westmarland, N. (2005.) Tackling Domestic Violence: effective interventions and approaches. Home Office. Available online at:

http://www.brokenrainbow.org.uk/sites/default/files/Home\%20Office\%20Tackling\%20Dome stic\%20Violence\%202005.pdf. Last accessed February 2017.

Harris, S. (2003) Inter-agency practice and professional collaboration: the case of drug education and prevention, Journal of Education Policy 18(3), pp.303-314.

Harvie, P., \& Manzi, T. (2011). Interpreting multi-agency partnerships: Ideology, discourse and domestic violence. Social \& Legal Studies, 20(1), 79-95.

Hill, J. S. K. (2001). Broadening the partnerships: experiences of working across community agencies. Journal of Interprofessional Care, 15(4), 341-350.

Her Majesty's Inspectorate of Constabulary. (2014). Everyone's business: Improving the police response to domestic abuse. London, England: HMIC.

Hoeffler, A., \& Fearon, J.(2015) Conflict and violence assessment paper: benefits and costs of the conflict and violence targets for the post-205 development agenda. Copenhagen

Consensus Centre. Available online at:

http://www.copenhagenconsensus.com/sites/default/files/conflict_assessment_-

hoeffler_and_fearon_0.pdf Last accessed February 2017.

Home Office. (2012). Domestic violence and abuse: detailed Guidance, Available online at: https://www.gov.uk/guidance/domestic-violence-and-abuse. Last accessed February 2017.

Home Office. (2014a). Strengthening the Law on Domestic Abuse Consultation- Summary of Responses. Available online at:

https://www.gov.uk/government/uploads/system/uploads/attachment_data/file/389002/Streng theningLawDomesticAbuseResponses.pdf. Last accessed February 2017.

Home Office. (2014b). Multi Agency Working and Information Sharing Project: Final Report. Available online at:

https://assets.publishing.service.gov.uk/government/uploads/system/uploads/attachment_data /file/338875/MASH.pdf 
Hymans, M. (2008). How personal constructs about "professional identity" might act as a barrier to multi-agency working. Educational Psychology in Practice, 24(4), 279-288.

Johnson, M., Cowin, L. S., Wilson, I., \& Young, H. (2012). Professional identity and nursing: contemporary theoretical developments and future research challenges. International nursing review, 59(4), 562-569.

Laming, H. B. (2009). The protection of children in England: A progress report (Vol. 330). The Stationery Office.

Lea, S. J., \& Callaghan, L. (2016). “It Gave Me My Life Back” An Evaluation of a Specialist Legal Domestic Abuse Service. Violence against women, 22(6), 704-721.

Lee, K. (2014) A DAARC Window of Opportunity. Ashurst: Hampton Trust. Available online at:

http://www.hamptontrust.org.uk/files/9114/1537/2778/DAARC_FINAL_VERSION_12_sept 2014.pdf Last accessed June 2017.

McInnes, K \& Newman, T (2006). Domestic Abuse in North Somerset: A Scoping Exercise. Barnardo's. Available online at:

http://www.barnardos.org.uk/domestic_abuse_in_north_somerset_a_scoping_exercise_june_

2006.pdf Last accessed February 2017.

Moran, P., Jacobs, C., Bunn, A., \& Bifulco, A. (2007). Multi-agency working: implications for an early-intervention social work team. Child \& Family Social Work, 12(2), 143-151.

Netto, G., Pawson, H \& Sharp, C. (2009). Preventing homelessness due to domestic violence: Providing a safe space or closing the door to new possibilities? Social Policy and Administration, 43(7), 719-735. doi:10.1111/j.1467-9515.2009.00691.x

NICE. (2013). Domestic violence and abuse - identification and prevention: draft guidance. Available online at: http://www.nice.org.uk/guidance/ph50/documents/domestic-violenceand-abuse-identification-and-prevention-draft-guidance2 Last accessed June 2017.

NICE. (2014). Domestic violence and abuse: multi-agency working. Available online at https://www.nice.org.uk/guidance/ph50/resources/domestic-violence-and-abuse-multiagency-working-1996411687621 Last accessed June 2017.

O'Carroll, V., McSwiggan, L., \& Campbell, M. (2016). Health and social care professionals' attitudes to interprofessional working and interprofessional education: A literature review. Journal of Interprofessional Care, 30(1), 42-49.

O’Doherty, L. J., Taft, A., Hegarty, K., Ramsay, J., Davidson, L. L., \& Feder, G. (2014). Screening women for intimate partner violence in healthcare settings: abridged Cochrane systematic review and meta-analysis. BMJ, 348, g2913.

O’Donnell, E., Atkinson, J. A., Freebairn, L., \& Rychetnik, L. (2017). Participatory simulation modelling to inform public health policy and practice: Rethinking the evidence hierarchies. Journal of Public Health Policy, 38(2), 203-215.

Office for National Statistics (2016) Domestic abuse in England and Wales: year ending March 2016 
https://www.ons.gov.uk/peoplepopulationandcommunity/crimeandjustice/bulletins/domestica buseinenglandandwales/yearendingmarch2016\#main-points (last accessed Feb 2017)

Part, D. (2006). A flexible response to domestic abuse: Findings from an evaluation, Practice: Social Work in Action, 18(1), 47-58. doi: 10.1080/09503150600577031

Peckover, S., Golding, B., \& Cooling, P. (2013). Multi-Agency Working in Domestic Abuse and Safeguarding Children. Available online at:

https://www.centreforwelfarereform.org/uploads/attachment/369/multi-agency-working-indomestic-abuse-and-safeguarding-children.pdf Last accessed November 2018..

Peckover, S \& Golding, B. (2015). Domestic Abuse and Safeguarding Children: Critical Issues for Multi-Agency Work. Child Abuse Review. doi: 10.1002/car.2392

Reeves, S., Zwarenstein, M., Goldman, J., Barr, H., Freeth, D., Koppel, I \& Hammick, M. (2010). The effectiveness of interprofessional education: Key findings from a systematic review. Journal of Interprofessional Care, 24(3), 230-241. doi: $10.3109 / 13561820903163405$

Rychetnik, L., Frommer, M., Hawe, P., \& Shiell, A. (2002). Criteria for evaluating evidence on public health interventions. Journal of Epidemiology \& Community Health, 56(2), 119127.

SafeLives (2016). Early Intervention is key to reducing domestic abuse. Available online at: http://www.safelives.org.uk/policy_blog/early-intervention-key-reducing-domestic-abuse Last accessed June 2017.

Sloper, P. (2004). Facilitators and barriers for co-ordinated multi-agency services. Child: care, health and development, 30(6), 571-580.

Stanley, N., Ellis, J., Farrelly, N., Hollinghurst, S., \& Downe, S. (2015). Preventing domestic abuse for children and young people: A review of school-based interventions. Children and youth services review, 59, 120-131.

Stanley, N., Miller, P., Richardson Foster, H \& Thomson, G. (2010). Children and families experiencing domestic violence: Police and children's social services' responses. NSPCC, London. Available online at:

https://library.nspcc.org.uk/HeritageScripts/Hapi.dll/filetransfer/2010ChildrenFamiliesExperi encingDomesticViolenceReport.pdf?filename=AA58F75CEDE68892A73FB681FE246B837 1684F102172D08A780A14959D3BCE5747137B3B2A935011CB8EC3068664FF481AA6D 2524E357BAB96C006752CCD756759AD77BD1E389823A55CFAAE74B2EE64F46C611 AD1724BE1AC500B025490CCB1CD8D9D26B00674E723A731951BB13FBE2976B21483 8E6BBB09ACFF55A26D6821D9328AD87D9BCBF6BDBD27311723ECA6954D33EE75E C43F3D7EC28E9D24A5C0FED55AC6F57157E239FE68446ECA5B81954E8BDD635A30 D2C087DB2CB759CA7E2F5CAE2BD376B638E\&DataSetName=LIVEDATA. Last accessed November 2018.

Stanley, N., Miller, P., Richardson-Foster, H \& Thopmson, G. (2011). Children's Experiences of Domestic Violence: Developing an Integrated Response From Police and Child Protection Services. Journal of Interpersonal Violence, 26(12), 2372-2391. doi: $10.1177 / 0886260510383030$ 
Stanley, N \& Humphreys, C. (2014). Multi-agency risk assessment and management for children and families experiencing domestic violence. Children and Youth Services Review, 47(1), 78-85. doi:10.1016/j.childyouth.2014.06.003

Stanley, N (2015). Breaking down barriers: New developments in multi-agency responses to domestic violence. Critical issues on violence against women: International perspectives and promising strategies. Johnson, Holly (Ed); Fisher, Bonnie S. (Ed); Jaquier, Véronique (Ed); pp. 131-141; New York, NY, US: Routledge/Taylor \& Francis Group; 2015. xxv, 267 pp.

Stevens, E. (2013). Safeguarding vulnerable adults: exploring the challenges to best practice across multi-agencysettings. The Journal of Adult Protection, 15(2), 85-95.

Stöckl, H., Devries, K., Rotstein, A., Abrahams, N., Campbell, J., Watts, C., \& Moreno, C. G. (2013). The global prevalence of intimate partner homicide: a systematic review. The Lancet, 382(9895), 859-865.

Taket, A. R. (2004). Tackling Domestic Violence: the role of health professionals. Home Office Research, Development and Statistics Directorate.

UK Government. (2004). Domestic Violence, Crime and Victims Act 2004. Avilable online at http://www.legislation.gov.uk/ukpga/2004/28/contents

Walby, S. (2009). The cost of domestic violence: Update 2009. Available online at: http://www.lancs.ac.uk/fass/doc_library/sociology/Cost_of_domestic_violence_update.doc Last accessed September 2016.

Warmington, P., Daniels, H., Edwards, A., Brown, S., Leadbetter, J., Martin, D., \& Middleton, D. (2004). Interagency Collaboration: a review of the literature. Teaching and Learning Research Council, Bath.

World Health Organization (2013). Global and regional estimates of violence against women: prevalence and health effects of intimate partner violence and non-partner sexual violence. http://apps.who.int/iris/bitstream/10665/85239/1/9789241564625_eng.pdf Last accessed February 2017

Yeung, H., Chowdhury, N., Malpass, A., \& Feder, G. S. (2012). Responding to domestic violence in general practice: a qualitative study on perceptions and experiences. International Journal of Family Medicine, 2012, 960523. 